\title{
$\mathrm{DJ}$ 解 \\ Volume 7 - Fall 2011 \\ djim.management.dal.ca
}

\section{The Case for Khadr: Why Failed Repatriation Means Failed Leadership for Stephen Harper}

\section{Lora Hamilton}

\begin{abstract}
This paper uses the Syncretic Steward framework to evaluate Stephen Harper's actions in regards to Omar Khadr, the Canadian detained by American forces in Guantanamo Bay. By applying appropriate metaphors to translate this framework from a managerial to a political sphere, I conclude that Harper has failed to demonstrate responsible leadership or to promote stewardship in the case of Omar Khadr.
\end{abstract}

About the Author(s): Lora Hamilton is currently enrolled in her first year of the Masters of Library and Information Sciences at Dalhousie, and holds a BMus (Hons.) from Wilfrid Laurier University. She is interested in how management theories can be extended to evaluate political actions. This paper was originally written for the Management without Borders course in the Faculty of Management at Dalhousie. 


\section{Introduction}

Omar Khadr has been held as an enemy combatant in the infamous Guantanamo Bay Detention Center for the past eight years. An alleged member of al-Qaeda, Khadr was accused of throwing a grenade that killed American soldier Sergeant First Class Christopher James Speer in Afghanistan in 2002, for which he was charged with war crimes. At the time Khadr was fifteen years old. Perhaps one of the most influential factors on the high level of attention this case received is the fact that Omar Khadr is a Canadian. Public opinion has been divided over what the government should do about a citizen who has been caught on the "wrong side" of the War on Terror: should his country abandon him to his fate at the hands of the American government when human rights violations are strongly suspected, if not proven, or should Khadr's government fight to repatriate him (Angus Reid Public Opinion, 2010)? The issue of repatriation and the state's responsibility to its citizens, particularly those who commit crimes away from home, is highly contested. As the current head of government, Stephen Harper is in a leadership position. By using a Syncretic Steward framework to relate major aspects of the Khadr case to criteria for successful responsible leadership, Stephen Harper's failure to repatriate Omar Khadr will be proven to be tantamount to failure as a responsible leader. Succeeding a brief description of the framework involved, the following issues as they relate to Omar Khadr's case will be examined: the influence of the United States, namely the Guantanamo Bay Detention Center; the influence of Canadians, both in public opinion and through the Supreme Court of Canada as a national institution; the shift in perception and treatment of children as minors, as child soldiers, and as enemy combatants; and repatriation as a state's responsibility to its citizens.

\section{Syncretic Stewardship as a Framework}

The Syncretic Steward framework uses four categories to evaluate whether responsible leadership is being successfully demonstrated. The four main categories of the framework are organizational accountability, stewardship, and stakeholder focus; social engagement for positive change; human rights governance and ethics; and sustainability (J. Barker, personal communication, Oct 2010; Berger, Cunningham, \& Drumwright, 2007). The leader is represented in the centre of the model, with the four categories listed above surrounding the centre. It is important to keep in mind that all of these areas are interconnected; they relate to each other as well as to the leader, who is in a central position. For this paper the leader in question is the Prime Minister of Canada, Stephen Harper, and this framework will evaluate whether he is successfully fulfilling the role of a steward. The metaphor of "organization" will be used to describe the Government of Canada; its actions are in question through Harper's 
leadership. The stakeholder metaphor will be used to describe parties who have a vested interest in the outcome of Khadr's case. One further modification of terminology is needed, this time for "sustainability". Sustainability carries environmental connotations, but the Khadr case, because it is a social one, requires a focus on social values. Therefore it is more appropriate to view "sustainability" in terms of preservation of values.

The stakeholders involved in this issue are important to identify because a leader must sincerely interact with her/his stakeholders in order to become a successful steward. In this case, one of the most obvious stakeholders is Omar Khadr, an individual who is being directly affected by his government's actions. As well, Stephen Harper's stakeholders include the Canadian public, which constitutes a diverse group. This group has a direct impact on whether the Prime Minister is able to maintain his leadership role. The Canadian public evaluates the suitability of political leaders through democratic processes (regular elections). Thus, Stephen Harper is directly affected by this stakeholder group and must consider its reaction for every leadership move he makes. Legal institutions also have a stakeholder relation with the Prime Minister. In the Khadr case the Supreme Court of Canada, as a legal body, became involved. This institution can be cited as a stakeholder because its purpose is to uphold and maintain Canadian law, which is a reflection of national values. This relationship will be further discussed later in this paper. Lastly, a more ambiguous stakeholder is involved in this case: the United States and its political relationship with Canada, which is expressed through the two political leaders. Thus, the main stakeholders involved in Omar Khadr's case are identified. These are complex relationships, often involving nebulous parties and outcomes which are difficult to predict. Regardless, it is important to evaluate Harper's interaction with his stakeholders in order to determine his level of success as a leader.

\section{The Influence of the United States and Guantanamo Bay Detention Center}

The United States has long been one of the most influential bodies on Canada. The two countries are neighbours on a continent occupied by very few nations. The United States is the only country directly bordering Canada, and also happens to be one of the most influential nations in the world. As a result, whenever the US makes a decision Canadian politicians are forced to weigh their response with heavy consideration to these factors. This has become even more of a reality in today's "post-9/11 world," and there has been a shift in focus to global leadership where leaders must develop a "fundamental understanding of the interconnectedness of the world" (European Foundation for Management Development, 2005, p. 2). Along with interconnectedness and global focus ethics have come to the fore in leadership. There is an inherent problem that comes as part of globalization: Pless and Maak (2005) refer to a combination of an "ethics challenge" and a "diversity challenge." It is important 
to balance stakeholder interactions, as complex and diverse as they are, with integrity and ethics; responsible leaders are proactive in order to ensure ethically sound decisions are made (Maak, 2007).

An analysis of the War on Terror is unmerited here, although this conflict is intrinsic to the Khadr case, as it is much too broad an undertaking. Instead focus will be placed on one outcome of this conflict: the Guantanamo Bay Detention Center. As Ahmad (2009) writes, Guantanamo Bay, as an institution and an extension of the American government, denies both the prisoners' rights and their humanity. By permitting the detention of a Canadian Citizen at Guantanamo Bay, Harper is accepting facility's legitimacy. Harper is supporting the interests of the United States, because he is accepting American authority in pursuing "justice" for a fallen American soldier. It appears that Harper places substantial value on relations with the United States, a sentiment that is not unprecedented with regards to political relations amongst nations. However, in order to meet criteria for responsible leadership, the leader must satisfy diverse stakeholder groups, not simply the biggest and most powerful.

\section{The Influence of Canadians: Public Opinion and the Supreme Court of Canada}

The Canadian people also form an important stakeholder group. Harper is the head of the Canadian Government and, as such, is responsible for answering to this group. One of the ways to judge whether the leader in question has satisfied the demands of the stakeholder is through surveys. One such survey, conducted in early 2010, indicates that Canadians were divided, almost in half, about whether the Canadian government should repatriate Omar Khadr; $40 \%$ felt the government should demand his repatriation, while $40 \%$ felt Khadr should remain in Guantanamo Bay to face American justice (Angus Reid Public Opinion, 2010). Because of this considerable divide, it is difficult to say whether the Canadian public, as a stakeholder group, was satisfied with the actions taken by Stephen Harper. However, newspapers can often serve as an unofficial meter for public views. Martin's polemic, "Canada Must Accept Khadr" points to the uncomfortable situation the government is in, but posits that, regardless, Canada must stomach its obligation to take responsibility for its citizens (Martin, 2010).

A powerful means of recourse given to the Canadian people is the legal system of Canada. This institution is tasked with upholding the country's law. Omar Khadr used this system in an attempt to force Harper to demonstrate organizational accountability (where "organization" refers to the Government of Canada with Harper as the leader): his case against the Prime Minister went all the way to the Supreme Court of Canada. This body ruled that the "appropriate remedy in this case is to declare that K[hadr]'s Charter rights were violated, leaving it to the government to decide how best to respond in light of current information, its 
responsibility over foreign affairs, and the Charter" (Supreme Court of Canada, 2010). The fact that this case proceeded to the highest legal authority in the country indicates that Khadr was unsatisfied with Stephen Harper's actions as a leader in refusing to repatriate Khadr. Khadr's dissatisfaction led him to pursue the case, but the case went to the Supreme Court because it had legal merit and was of public importance. 2 The ruling by the Court states that Khadr's right to liberty and security of person were violated, and held Canada responsible for allowing this to happen (Supreme Court of Canada, 2010). However, Harper chose not to act to rectify this violation, namely by removing Khadr from his harmful situation. As a result, he was effectively abandoning a Canadian to continuous suffering. By doing this, he failed to demonstrate responsible leadership; his organization refused to account for and rectify an error of which he was explicitly informed.

According to Hernandez (2008), stewardship is fostered through a continuous, dynamic relationship between leader and follower. There is a social contract between the two parties where the follower is vulnerable in some way, and the leader is trusted to "avoid exposing the follower to undue harm or loss" (Hernandez, 2008, p. 123). There is a glaring discrepancy between the actions of Stephen Harper in regards to Omar Khadr as an individual and the relationship between a leader and a follower where the leader demonstrates effective stewardship. Stewardship is an intergenerational concept: successive generations inherit obligations and sentiments and bestow them on their steward (Hernandez, 2008). Moreover, there is an understanding that the steward will act for the benefit of the many (Hernandez, 2008). By choosing to ignore the message sent by the Supreme Court of Canada and allowing Khadr's rights to continually be violated, Harper was also sending a message that Canadians, under his leadership, may be abandoned to their (unconstitutional) fates if they stray outside of Canada and commit crimes. This undermines the stewardship theory advanced by Hernandez in that it deteriorates trust in the Canadian government for future, and current, generations. Thus, Harper has failed to foster effective stewardship.

\section{Shift of Perception and Treatment of Children as Minors, Child Soldiers, Enemy Combatants}

The next aspect of the Syncretic Steward framework under examination will be the "social engagement for positive change." This framework proves to be particularly relevant regarding Stephen Harper's leadership involving Omar Khadr. First it is important to remember that when he was captured Khadr was fifteen years old - a minor. However, upon entering Guantanamo Bay he became, in the eyes of those pursuing "justice," an adult. His treatment by the United States has been in violation of United Nations protocol1 which requires the rehabilitation of child soldiers, as well as international juvenile justice standards (Steinberg, 2009). While it may seem shocking that a minor can be treated with disregard to United Nations' conventions, 
especially in a developed nation like the United States, scholarship has marked the transition from children as children to child soldiers to enemy combatants. For instance, in his work as a psychologist involved with Omar Khadr's case, Steinberg, uses scientific knowledge to base his opinions on an individual who is, medically, a "juvenile" (Steinberg, 2009). This is in direct opposition to how the prosecution viewed Khadr: as an enemy combatant. However, by basing his interpretation in neuroscience, Steinberg refutes the fact that juveniles should be treated as adults under the law, regardless of the political climate generated by the War on Terror (Steinberg, 2009).

The "child soldier" seems to be a middle step between Steinberg's "juvenile" and the United States' "enemy combatant." The classification of Omar Khadr as an "enemy combatant" instead of a "child soldier" reveals two things. First, the fact that the "child" has been removed implies that the prosecution wants to diminish the fact that Khadr was, at the time of arrest, a minor. Secondly, "enemy combatant" implies guilt and much greater inherent violence; it gives the impression of justification of whatever actions the prosecution desires. The term "enemy combatant" has made its way into mainstream media; it appears in a Canadian public opinion poll about the Khadr case (Angus Reid Public Opinion, 2010). As a term, "enemy combatant" directly reflects the political climate surrounding the War on Terror: juveniles involved in armed conflicts that are part of the War on Terror" are treated differently than those who are not. Hyndman uses Omar Khadr and Ishmael Beah as cases to illustrate this dichotomy; Khadr is directly involved in the War on Terror, while Beah was not, and the two experienced completely different treatment at the hands of officials (Hyndman, 2010). Beah has been "rehabilitated," a process that involved being told that violence, killing people, and being a "child soldier" were not his fault. Beah has become an author and he has re-entered society as a productive member (Hyndman, 2010). Alternatively, Khadr has not re-entered society nor been rehabilitated: he was, instead, imprisoned and held accountable through the pursuit of justice.

By allowing the United States to treat a juvenile as an adult, and by allowing the United States to detain a Canadian citizen classified as an enemy combatant in an institution that "constituted a clear violation of Canada's international human rights obligations" (Supreme Court of Canada, 2010), Stephen Harper declined to socially engage for positive change. $\mathrm{He}$ instead chose to support a regime condemned by the highest legal authority in Canada, the Supreme Court. The view could be taken that by leaving Khadr in the hands of the Americans Harper was protecting Canadians from a dangerous individual. However, this speaks to the highly politically charged atmosphere surrounding the "war on terror" which removes crucial aspects of the individual's identity, like the fact that he was a minor at the time of the alleged crime and subsequent arrest. Canada's justice system should be suitably equipped to process a fifteen-year-old boy, even one who has found himself in the midst of an international conflict.

Opportunities for "social engagement for positive change" were plentiful in the case of Omar Khadr. A responsible leader could have seized it as a chance to promote the rights of children, 
to pursue justice without succumbing to the highly-charged political climate of enemy combatants, and the promotion of human rights values that are expected of governing bodies. If Harper were to promote positive change, he would push for rehabilitation of child soldiers, even if they are tagged as "enemy combatants." Roméo Dallaire points out that what occurred in this case goes against the Geneva Conventions' criteria for the treatment of child soldiers (cited in Hampson, 2010); this case goes directly against positive change, and therefore is also incompatible with responsible leadership. Moreover, to promote positive change, Harper would also strive to preserve the rights of every Canadian, especially when the Supreme Court of Canada recognizes that Charter rights are in jeopardy (Supreme Court of Canada, 2010). The European Foundation for Management Development (2005) states: "global regulation has not kept pace with globalization." Therefore, it becomes the onus of responsible leaders to promote positive change, regardless of whether strictly legal obligations have been met; they must choose to be ethical and to push for positive change.

\section{Human Rights Governance}

Guantanamo Bay Detention Center, as previously discussed, is an institution which denies the rights and humanity of its detainees (Ahmad, 2009; Supreme Court of Canada, 2010). Because of this, the situation Omar Khadr found himself in and Stephen Harper's resulting actions relate directly to the next section of the Syncretic Steward framework: human rights governance and ethics. The human rights aspects of this case are closely tied to the discussion of opportunity for social engagement for positive change. Credible sources (Ahmad, 2009; Supreme Court of Canada, 2010) noted the rights violations occurring at the American detention center, and the questionable tactics used to obtain justice in Guantanamo Bay for American losses during the War on Terror were well-publicized in the media (Keller, 2010). The United States chose to classify certain detainees as "unlawful combatants," which excludes them from the Geneva Conventions (Schneider, 2004). This is a distinction that is based mostly, if not purely, on political motivations; by excluding detainees from the Geneva Conventions, the United States felt it was justified in treating them outside of acceptable bounds of human rights.

The concept of "ethical intelligence" is very important to leadership, and once developed, can be used to solve problems where more than one "right" solution is available (Pless and Maak, 2005). In other words, Pless and Maak (2005) argue that ethical intelligence can "help global leaders to better assess situations from a moral point of view" (p. 4). It allows leaders to reflect on their own, and others', values and to create solutions involving complex stakeholders that are ethically upstanding (Pless and Maak, 2005). The concept of "ethical intelligence" respects that there exists a skill which allows leaders to successfully navigate complex situations while behaving in an "ethical" fashion. Based on this conclusion, responsible leadership in the case of Omar Khadr would have developed a creative solution that would have preserved the rights 
of the individual involved (Khadr), and would have also appeased the Canadian public and the United States as stakeholders. A responsible leader, one demonstrating ethical intelligence, would recognize that the immediate moral concern is the human rights violations that are occurring against one of the individuals to whom the world leader is responsible.

"Human rights are fundamental to the United Nations" is the first line of the United Nations' document on human rights (United Nations, 2010). This provides an explicit statement that should direct the moral compass of a responsible leader: the protection of human rights is paramount. Therefore, protecting the rights of Omar Khadr, both as a Canadian and as a global citizen to whom human rights are owed, is the obligation of a responsible leader. By failing to do this, Stephen Harper failed to demonstrate responsible leadership, especially from the "human rights governance and ethics" perspective of the Syncretic Steward framework.

\section{Repatriation as the State's Responsibility}

The last category of the Syncretic Steward framework is "sustainability." As mentioned previously, in the case of Omar Khadr and Stephen Harper, this relates more closely to the concept of "preservation of values," as it is a social case instead of an environmental one. As a socially-based case the sustainability, or preservation, of values can be linked to "social capital" developed and sustained by a responsible leader. Social capital, according to Maak (2007), is the accumulation of social resources such as goodwill, trust, and relationships that allow people to act collectively. A leader who builds social capital, because $s / h e$ is able to create valuable relationships with her/his stakeholders, is therefore a responsible one.

In the case of Omar Khadr, repatriation is a central issue to social capital; by repatriating a citizen who has been subjected to questionable treatment at the hands of another nation, the leader is able to build social capital within his own nation. More explicitly, had Harper chosen to repatriate Khadr, he would have shown that the protection of Canadians from human rights violations is an important value worth preserving. This would have built social capital in the form of trust. Canadians would have seen that, upon being accused of a crime and subjected to questionable practices in the pursuit of justice at the hands of another nation, they could trust that their leader would assure that they were protected.

Honig writes about the "decisionistic" nature of emergency politics, where powers of governance are shifted from proceduralized to discretionary domains; this creates unaccountable agencies within the government (Honig, 2005). This lack of accountability goes directly against the idea of social capital built on mutually beneficial, trust-based relationships. While perhaps the idea of "emergency politics" relates more closely to the American treatment of detainees involved in the War on Terror, by allowing a Canadian to succumb to these forces, Stephen Harper was, essentially, endorsing this lack of accountability. Accountability of 
an organization and its leader creates trust between the leader and the stakeholders, which in turn creates social capital. Therefore, Harper neglected an opportunity for sustainability of social capital.

Further solidifying Harper's inherent responsibility to Khadr is the following claim: "the decision to allow entry into the political community, and to become a citizen-subject of the sovereign, must be a decision without recourse, without appeal, and without debate" (Salter, 2008, p. 368). Because Khadr is a Canadian, which means he is a "citizen-subject of the sovereign," Harper, as the head of the government, must accept his responsibility to this individual. He must afford him access to all the rights of Canadians and must act to do so, especially when informed in no uncertain terms of the violation of rights that Khadr faced.3 Therefore, by choosing not to repatriate Khadr and have him face justice according to the rights afforded to him as a Canadian Harper was acting irresponsibly; he failed to sustain social capital in the form of trusting relationships between the head of government and its citizens. This failed repatriation has wider ramifications when viewed in consideration of the Canadian public. Harper sent the message that if a Canadian commits a crime outside of Canada, s/he is apt to be abandoned by her/his government to face the consequences, even if these include violations of Charter rights or even human rights violations. This is contrary to the sustainability of values of a nation as a protector of its citizens, and the sustainability of the image of Canada as a safe, respectful, protective nation, especially in terms of rights and freedoms.

\section{Conclusion}

Having analyzed Stephen Harper's leadership in the context of Omar Khadr's case using the Syncretic Steward framework, it becomes apparent that responsible leadership was not attained. Stakeholder engagement with some groups was successful, such as with the United States, whereby Harper allowed the US to pursue justice according to their preferences. The success of stakeholder engagement with regards to the Canadian public was undetermined, whereas the success in terms of individual engagement with Omar Khadr was not achieved. From this, it is possible to conclude that stewardship, especially according to Hernandez (2008), was achieved on some levels, but overall it was neglected. The subsequent categories of the framework are "social engagement for positive change" and "human rights governance and ethics." These two are closely-related in regards to Omar Khadr's case, and Stephen Harper missed crucial opportunities to promote positive change by failing to protect human rights and act in an ethical manner. Lastly, "sustainability," which is more aptly described here as "preservation of values" was unsuccessful due to failed repatriation. Harper was unable to repatriate Khadr in order to protect him from gross violations of rights, both Charter-based and internationally (human rights), which reflects poorly on Harper's desire and ability to protect Canadians who find themselves in unfortunate international situations. As well, Harper's actions show that he is willing to succumb to questionable practices that reflect purely political 
motivations, as seen by the United States' treatment of "enemy combatants," who are, as in Khadr's case, minors. This has detrimental resonance on social capital, which is fundamental to responsible leadership. Therefore, having considered all the aspects of the Syncretic Stewardship framework, Stephen Harper, by failing to repatriate Omar Khadr, and thereby failing to protect a vulnerable Canadian, has failed to demonstrate responsible leadership.

Notes:

1. United Nations' "Optional Protocol" to the Convention on the Rights of the Child on the Involvement of Children in Armed Conflict

2. "In most cases, appeals are heard by the Court only if leave to appeal is given. Such leave, or permission, will be given by the Court when a case involves a question of public importance." (Supreme Court of Canada, 2011). 3. This is referring to the Supreme Court of Canada ruling that Khadr's rights as a Canadian were being violated at Guantanamo Bay Detention Center (Supreme Court of Canada, 2010). 


\section{References}

Ahmad, M.L. (2009). Resisting Guantanamo: Rights at the brink of dehumanization. Northwestern University Law Review, 103(4), 1683-1763.

Angus Reid Public Opinion. (2010, Feb 4). Canadians remain staunchly divided over Omar Khadr's fate: Almost half of respondents believe the Supreme Court made the right call in ruling that the federal government cannot be forced to repatriate Khadr. Retrieved from

http://www.visioncritical.com/wpcontent/uploads/2010/02/2010.02.03 Khadr CAN.pdf

Angus Reid Public Opinion. (2010, Feb 4). Omar Khadr case still divides views in Canada. Retrieved from http://www.angusreid.com/polls/38248/omar khadr case still divides views in canada/

Berger, I.E., Cunningham, P.H.,\& Drumwright, M.E. (2007). Mainstreaming corporate social responsibility: Developing markets for virtue. California Management Review, 49(4), 132-157.

European Foundation for Management Development. (2005). Globally responsible leadership: A call for engagement. Globally Responsible Leadership Initiative. Retrieved from http://www.grli.org/images/stories/grli/documents/globally responsible leadership repor t.pdf

Hampson, S. (2010, Nov 3). Roméo Dallaire rages against Canada. The Globe and Mail. Retrieved from http://www.theglobeandmail.com/life/family-and-relationships/sarahhampson/romo-dallaire-rages-against-canada/article1784505/

Hernandez, M. (2008). Promoting stewardship behavior in organizations: A leadership model. Journal of Business Ethics, 80(1), 121-128. CrossRef

Honig, B. (2005). Bound by law? Alien rights, administrative discretion, and the politics of technicality: Lessons from Louis Post and the first Red Scare. In A. Sarat, L. Douglas, \& M. Umphrey (Eds.), The limits of law (209-245). Stanford: Stanford University Press.

Hyndman, J. (2010). The question of "the political" in critical geopolitics: Querying the "child soldier" in the "war on terror." Political Geography, 29(5), 247-255. doi: 10.1016/j.polgeo.2009.10.010 CrossRef

Keller, T. (2010, Oct 28). Stalin would have been proud. National Post. Retrieved from http://www.nationalpost.com/Stalin+would+have+been+proud/3737862/story.html 
Maak, T. (2007). Responsible leadership, stakeholder engagement, and the emergence of social capital. Journal of Business Ethics, 74, 329-343. doi: 10.1007/s10551-007-9501-5 CrossRef

Martin, D. (2010, Oct 26). Canada must accept Khadr. National Post. Retrieved from http://www.nationalpost.com/Canada+must+accept+Khadr/3726466/story.html

Pless, N.M. \& Maak, T. (2005). Relational intelligence for leading responsibly in a connected world. Academy of Management Proceedings, 1-6.

Salter, M. B. (2008). When the exception becomes the rule: Borders, sovereignty, and citizenship. Citizenship Studies, 12(4), 365-380. doi: 10.1080/1361020802184234 CrossRef

Schneider, D. (2004). Human rights issues in Guantanamo Bay [abstract]. Journal of Criminal Law, 68(5), 423-439. CrossRef

Steinberg, L. (2009). Should the science of adolescent brain development inform public policy? American Psychologist, 64(8), 739-750. doi: 10.1037/0003-006X.64.8.739 CrossRef

Supreme Court of Canada. (2010, Jan 29). Canada (Prime Minister) v. Khadr, 2010 SCC 3 , [2010] 1S.C.R. 44. Retrieved from http://scc.lexum.umontreal.ca/en/2010/2010scc3/2010scc3.html

Supreme Court of Canada. (2011, April 11). Supreme Court of Canada - Questions and answers. Retrieved from http://www.scc-csc.gc.ca/faq/faq/index-eng.asp

United Nations. (2010). Human rights. Retrieved from http://www.un.org/Depts/dhl/resguide/spechr.htm 